\title{
PENINGKATAN KETERAMPILAN MENYIMAK BERITA DENGAN MEDIA AUDIO VISUAL SISWA SMP PLUS DARUSSALAM BLOKAGUNG BANYUWANGI
}

\author{
Muhammad Hasbullah Ridwan \\ Institut Agama Islam Darussalam (IAIDA) Banyuwangi \\ Email: ridwan_hasbullah@yahoo.com
}

\begin{abstract}
This study was designed using the method of action research (action research). The research objective of this class action to overcome the problem of the ability of listening skills. Because the real conditions that occur in class VIII SMP Plus Darussalam are still lacking, because during this time the learning activities are still many teachers who are reluctant to use the media. Media used are media Audio Visual techniques of group work. The research process begins with the initial observation and two cycles. The effectiveness of the actions in each cycle is measured from the observation and assessment activities in two ways, namely product assessment and appraisal process. Meanwhile, the data of listening skills through audiovisual media methods of group work techniques is analyzed by describing the average value of per cycle so the results can reach the learning target of $75 \%$. The average yield on the class of initial observations is $71.6 \%$ and the results of the first cycle the average ability listening is $75.125 \%$, while in the second cycle is $87.50 \%$. Based on the results of 1 and 2 of the decision can be taken, namely: 1.kemampuan listening through audiovisual media techniques of group work in class VIII SMP Plus Darussalam Blokagung Tegalsari fairly good Banyuwangi, 2. The use of audio-visual media in improving listening skills was quite successful.
\end{abstract}

Keywords: Improvement, Skills, Listening, Audio

\begin{abstract}
Abstrak
Penelitian ini dirancang menggunakan Metode Penelitian Tindakan (action research). Tujuan penelitian tindakan kelas ini untuk mengatasi masalah kemampuan keterampilan menyimak. Karena kondisi riil yang terjadi di siswa kelas VIII SMP Plus Darussalam masih kurang, karena selama ini kegiatan pembelajaran masih banyak guru yang enggan memanfaatkan media. Media yang digunakan yaitu media Audio Visual dengan teknik kerja kelompok. Proses penelitian ini diawali dengan pengamatan awal dan dua siklus. Keefektifan tindakan pada setiap siklus diukur dari hasil observasi dan penilaian kegiatan menggunakan dua cara yaitu penilaian produk dan penilaian proses. Sementara itu data hasil kemampuan menyimak melalui metode media Audio visual teknik kerja kelompok dianalisis dengan cara mendeskripsikan nilai rata-rata antar per siklus sehingga hasilnya dapat mencapai targer pembelajaran yaitu $75 \%$. Hasil rata-rata kelas pada pengamatan awal yaitu : 71,6\% dan Hasil pada siklus I rata-rata kemapuan menyimak adalah 75,125\% sedangkan pada siklus II yaitu 87,50 \%. Berdasarkan hasil 1 dan 2 tersebut dapat diambil keputusan yaitu:1.
\end{abstract}


Jurnal Darussalam; Jurnal Pendidikan, Komunikasi dan Pemikiran Hukum Islam Vol. IX, No 1: 32-49. September 2017. ISSN: 1978-4767 (Cetak), ISSN: 2549-4171 (Online)

Kemampuan menyimak melalui media Audio visual teknik kerja kelompok di kelas VIII SMP Plus Darussalam Blokagung Tegalsari Banyuwangi terbilang baik, 2. Penggunaan media Audio visual dalam peningkatan keterampilan menyimak cukup berhasil.

\section{Kata Kunci: Peningkatan, keterampilan, Menyimak, Audio Visual}

\section{A. Latar Belakang}

Keterampilan menyimak merupakan salah satu keterampilan berbahasa yang harus dipelajari disetiap jenjang pendidikan, begitu juga dijenjang pendidikan sekolah menengah pertama. Hal ini berdasarkan kurikulukm bahasa Indonesia menyebutkan bahwa salah satu standar kompetensi bahan kajian keterampilan mendengarkan untuk siswa kelas VIII SMP semester II adalah, 9. Memahami isi berita radio/televisi yang disampaikan dengan media audio visual, sedangkan pada kompetensi dasar adalah, 9.1 Menemukan pokok-pokok berita (apa, siapa, mengapa, di mana, kapan, dan bagaimana) yang didengar atau ditonton melalui radio/televisi dan 9.2 Mengemukakan kembali berita yang didengar/ditonton melalui radio/ televisi. Berdasarkan kurikulum tersebut materi menyimak harus diperhatikan. Keterampilan menyimak siswa kelas VIII SMP Plus Darussalam Blokagung Banyuwangi berdasarkan hasil wawancara dan penelitian awal masih kurang. Karena selama ini kegiatan pembelajaran masih banyak guru yang enggan memanfaatkan media yang tersedia. Adapun masalah yang timbul diantaranya: (1) siswa belum banyak yang dapat menyampaikan kembali hasil simakan dengan benar, (2) siswa belum dapat menyampaikan simakan dengan bahasa yang baik, benar, dan runtut. Hal ini keterlibatan siswa pada simakan hanya pada kegiatan tanya jawab yang dipandu oleh guru, (3) Siswa cenderung mengikuti proses kegiatan belajar mengajar apa adanya. Belum ada penampakan kesempatan yang diperoleh siswa untuk kreatif melakukan proses belajar, dan (4) strategi dan teknik guru dapat dikatakann masih klasikal, terlebih lagi hal ini dilakukan dengan alasan dalam rangka mencapai tujuan target kurikulum. 
Jurnal Darussalam; Jurnal Pendidikan, Komunikasi dan Pemikiran Hukum Islam

Vol. IX, No 1: 32-49. September 2017. ISSN: 1978-4767 (Cetak), ISSN: 2549-4171 (Online)

\section{B. Tujuan Penelitian}

Berdasarkan permasalahan pembelajaran, penelitian ini bertujuan untuk Meningkatkan keterampilan menyimak siswa kelas VIII SMP Plus Darussalam Blokagung Tegalsari Banyuwangi.

\section{Manfaat penelitian}

Adapun manfaat yang dapat diambil dari penelitian ini yaitu: Penelitian ini diharapkan dapat memberi sumbangan ilmu pengetahuan khususnya tentang penggunaan metode media Audio Visual sebagai usaha untuk meningkatkan kemampuan menyimak siswa SMP Plus Darussalam Blokagung Banyuwangi dan penelitian ini diharapkan dapat memberikan sumbangan teori pembelajaran guna meningkatkan keterampilan menyimak siswa kelas VIII SMP Plus Darussalam Blokagung Banyuwangi

\section{Metode Penelitian}

Penelitian ini dirancang untuk meningkatan keterampilan menyimak siswa kelas VIII SMP Plus Darussalam Blokagung Banyuwangi melalui media Audio Visual dengan teknik kerja kelompok. Berdasarkan tujuan tersebut rancangan yang digunakan dalam hal ini adalah penelitian tindakan kelas (PTK). Penelitian ini dilaksanakan secara kolaboratif antara peneliti dan guru mata pelajaran bahasa Indonesia kelas VIII SMP Plus Darussalam Blokagung Banyuwangi.

\section{Setting Penelitian Dan Subjek Penelitian}

Penelitian ini dilakukan disekolah SMP Plus Darussalam, sekolah ini sekolah swasta yang berada dalam naungan yayasan Darussalam dan bertempat di Dusun Blokagung Desa Karangdoro Kecamatan Tegalsari Kabupaten Banyuwangi. Siswa yang dijadikan subjek penelitian adalah siswa kelas VIII dengan jumlah siswa 30 .

\section{Instrument penelitian}

Dalam penelitian ini, peneliti bertindak sebagai instrument kunci. Keseluruhan perencanaan, pengamatan, pencatatan, dan penganalisisan proses serta hasil penelitian dilakukan oleh peneliti. 
Jurnal Darussalam; Jurnal Pendidikan, Komunikasi dan Pemikiran Hukum Islam

Vol. IX, No 1: 32-49. September 2017. ISSN: 1978-4767 (Cetak), ISSN: 2549-4171 (Online)

\section{Teknik Pengumpulan Data}

Dalam penelitian tindakan kelas ini teknik yang digunakan dalam pengumpulan data melalui tekni observasi.

\section{Analisis Penelitian}

Dalam Penelitian Tindakan Kelas (PTK) analisis data dilakukan oleh peneliti pada setiap aspek kegiatan penelitian. Adapun data yang dianalisis adalah hasil evaluasi kemampuan menyimak siswa untuk memperoleh nilai rata-rata dan analisis tersebut dengan memelakukan observasi.

\section{Prosedur Penelitian}

Dalam penelitian tindakan kelas prosedur penelitian terdapat dua hal yong pokok yaitu: Persiapan Penelitian Dalam proses persiapan kegiatan diawali dengan melakukan pengamatan awal terhadap kegiatan pembelajaran menyimak di kelas VIII SMP Plus Darussalam Blokagung Banyuwangi. Setelah diperoleh temuan proses dan hasil pembelajaran menyimak kemudian disusun rencana tindakan pembelajaran menyimak dengan media Audio Visual. Pelaksanaan Penelian. Secara umum penelitian tindakan kelas dilaksanakan dalam bentuk siklus berulang-ulang, empat bagian utama yang ada dalam setiap siklus adalah sebagai berikut:1) perencanaan, 2)pelaksanaan, 3) observasi, 4) refleksi. Pelaksanaan penelitian tindakan kelas merupakan kegiatan kolaborasi antara peneliti dan guru.

\section{E. Hasil}

Pada bab ini akan diuraikan: (a) Hasil Pengamatan Awal, dan (b) Hasil penelitian siklus I dan siklus II,

\section{Hasil Pengamatan Awal}

Pengamatan kondisi pra tindakan dilakukan sebelum peneliti melakukan proses penelitian. Pengamatan ini dilakukan dengan cara observasi langsung dan wawancara dengan guru kelas yang bertindak sebagai guru kulaburator. Hasil dari pengamatan awal dijadikan pedoman dalam melaksanakan penelitian. Pengamatan tersebut dilakukan pada tangga 21April 2014 pada pukul 13.00 Wib sampai dengan pukul 14.00 Wib ( pada jam ke-3 dan ke-4). Pengamatan dilakukan pada 
Jurnal Darussalam; Jurnal Pendidikan, Komunikasi dan Pemikiran Hukum Islam Vol. IX, No 1: 32-49. September 2017. ISSN: 1978-4767 (Cetak), ISSN: 2549-4171 (Online)

saat pembelajaran mata pelajaran Bahasa Indonesia di kelas VIIISMP Plus Darussalam Blokagung Tegalsari Banyuwangi.

\begin{tabular}{|c|c|c|c|c|}
\hline No & Nama siswa & Nilai & Tuntas & Tidak Tuntas \\
\hline 1 & Anggun Putri Pertiwi & 75 & $\sqrt{ }$ & \\
\hline 2 & Aulia nikmatul maula & 85 & $\sqrt{ }$ & \\
\hline 3 & Dewi lyien ien & 75 & $\sqrt{ }$ & \\
\hline 4 & Diana Novita Sari & 75 & $\sqrt{ }$ & \\
\hline 5 & Elia Hani Safitri & 75 & $\sqrt{ }$ & \\
\hline 6 & Evi Nur Azizah & 80 & $\sqrt{ }$ & \\
\hline 7 & Iqlima Nur Faizah & 75 & $\sqrt{ }$ & \\
\hline 8 & Jihan Nafiatul Amalia & 75 & $\sqrt{ }$ & \\
\hline 9 & Lu'luil Maknun & 75 & $\sqrt{ }$ & \\
\hline 10 & Lutfi Rahayu & 75 & $\sqrt{ }$ & \\
\hline 11 & Miftahul hidayah & 60 & & $\sqrt{ }$ \\
\hline 12 & Miranda Wardaniyah & 60 & & $\sqrt{ }$ \\
\hline 13 & Mufarikatuz Zuhdataini & 70 & & $\sqrt{ }$ \\
\hline 14 & Nadia Fitriatus Sholihah & 70 & & $\sqrt{ }$ \\
\hline 15 & Nadia Ilma Rohestina & 70 & & $\sqrt{ }$ \\
\hline 16 & Nadiatus Sholehah & 69 & & $\sqrt{ }$ \\
\hline 17 & Nafisatul Imamah & 65 & & $\sqrt{ }$ \\
\hline 18 & Nurma Indana Zulfa & 70 & & $\sqrt{ }$ \\
\hline 19 & Mufarikatuz Zuhdataini & 65 & & $\sqrt{ }$ \\
\hline 20 & Nadia Fitriatus Sholihah & 65 & & $\sqrt{ }$ \\
\hline 21 & Nadia Ilma Rohestina & 75 & $\sqrt{ }$ & \\
\hline 22 & Nadiatus Sholehah & 65 & & $\sqrt{ }$ \\
\hline 23 & Nafisatul Imamah & 77 & & \\
\hline 24 & Nurma Indana Zulfa & 60 & & $\sqrt{ }$ \\
\hline 25 & Mufarikatuz Zuhdataini & 75 & $\sqrt{ }$ & $\sqrt{ }$ \\
\hline 26 & Nadia Fitriatus Sholihah & 60 & & $\sqrt{ }$ \\
\hline 27 & Nadia Ilma Rohestina & 77 & $\sqrt{ }$ & \\
\hline 28 & Nadiatus Sholehah & 76 & $\sqrt{ }$ & \\
\hline 29 & Nafisatul Imamah & 79 & $\sqrt{ }$ & \\
\hline 30 & Nurma Indana Zulfa & 75 & $\sqrt{ }$ & \\
\hline \multicolumn{2}{|c|}{ Jumlah } & 2148 & & \\
\hline \multicolumn{2}{|c|}{ Rata-rata } & 71.6 & & \\
\hline \multicolumn{2}{|c|}{ Persentase } & & $55 \%$ & $45 \%$ \\
\hline
\end{tabular}

\section{Hasil Penelitian Siklus 1}

Sebelum tindakan penelitian dilaksanakan terlebih dahulu disusun perencanaan yang disusun oleh guru mata pelajaran dan peneliti yang dilakukan pada hari kamis tanggal 29 April 2014 di ruang guru. Akhir diskusi diperoleh kesepakatan bahwa pelaksanaan tindakan siklus I akan dilaksanakan pada hari senin tanggal 05 Mei 2014 dan rabo 07 Mei 2014 dilaksanakan selama 2 jam pelajaran ( 2 x 40 menit) pukul 12.40 Wib s/d pukul 13.20 Wib. Kegiatan tersebut disajikan sebagai berikut. 


\section{Kegiatan Pendahuluan Pembelajaran}

Kegiatan pendahuluan pembelajaran berupa ucapan salam, penyampaian tujuan pembelajaran yang akan disampaikan, pengarahan yang berupa penjelasan mengenai pelaksanaan pembelajaran dan memotivasi siswa agar lebih giat dalam mengikuti setiap pelaksanaan pembelajaran. Kegiatan pendahuluan pembelajaran dilaksanakan selam 20 menit. Penggunaan waktu tersebut telah sesuai alokasi waktu yang tersedia.

\section{Kegiatan Inti Pembelajaran}

Aktivitas pembelajaran pada dalam kegiatan inti adalah(1) menyiapkan perangkat, (2) pembentukan kelompok,(3) mengatur tempat duduk siswa dan pengondisian kelas, (4)pembagian kertas untuk catatan setiap siswa, (5) menyimak materi yang di tayangkan guru, (6) mencatat apa yang didengar dari materi yang ditayangkan, (7)berdiskusi untuk membuat rangkuman dari hasil simakan,dan (8) menyampaikan hasil rangkuman, (8) mengevaluasi hasil rangkuman

\begin{tabular}{|c|l|l|l|l|l|}
\hline \multirow{2}{*}{ NO } & \multicolumn{5}{|c|}{ NAMA KELOMPOK } \\
\cline { 2 - 6 } & \multicolumn{2}{|c|}{ I } & \multicolumn{1}{|c|}{ III } & \multicolumn{1}{c|}{ IV } & \multicolumn{1}{|c|}{ I } \\
\hline 1 & $\begin{array}{l}\text { Anggun Putri } \\
\text { Pertiwi }\end{array}$ & $\begin{array}{l}\text { Iqlima Nur } \\
\text { Faizah }\end{array}$ & $\begin{array}{l}\text { Mufarikatuz } \\
\text { Zuhdataini }\end{array}$ & $\begin{array}{l}\text { Nurul } \\
\text { Fitriyani }\end{array}$ & $\begin{array}{l}\text { Veni Nurita } \\
\text { Sari }\end{array}$ \\
\hline 2 & $\begin{array}{l}\text { Aulia nikmatul } \\
\text { maula }\end{array}$ & $\begin{array}{l}\text { Jihan Nafiatul } \\
\text { Amalia }\end{array}$ & $\begin{array}{l}\text { Nadia Fitriatus } \\
\text { Sholihah }\end{array}$ & $\begin{array}{l}\text { Rona } \\
\text { Rizqotul } \\
\text { Izzah }\end{array}$ & $\begin{array}{l}\text { Vina Nailil } \\
\text { Faza }\end{array}$ \\
\hline 3 & Dewi lyien ien & $\begin{array}{l}\text { Lu'luil } \\
\text { Maknun }\end{array}$ & $\begin{array}{l}\text { Nadia Ilma } \\
\text { Rohestina }\end{array}$ & $\begin{array}{l}\text { Shanggita } \\
\text { Dewi }\end{array}$ & $\begin{array}{l}\text { Vina } \\
\text { rohmatul } \\
\text { Fitriah }\end{array}$ \\
\hline 5 & $\begin{array}{l}\text { Diana Novita } \\
\text { Sari }\end{array}$ & Elia Hani Safitri & $\begin{array}{l}\text { Miftahul Rahayu } \\
\text { hidayah }\end{array}$ & $\begin{array}{l}\text { Nadiatus } \\
\text { Sholehah }\end{array}$ & Nafisatul Imamah \\
Siti Alfarida & $\begin{array}{l}\text { Zuhroina } \\
\text { Nur Fuadah }\end{array}$ \\
\hline 6 & Evi Nur Azizah & $\begin{array}{l}\text { Miranda } \\
\text { Wardaniyah } \\
\text { Fitriah }\end{array}$ & $\begin{array}{l}\text { Mecca } \\
\text { nurrofi P }\end{array}$ \\
\hline Zulfa Indana & $\begin{array}{l}\text { Uwaisa } \\
\text { Qornia }\end{array}$ & $\begin{array}{l}\text { Nur Ruyadh } \\
\text { Fitri }\end{array}$ \\
\hline
\end{tabular}

Penilaian yang dilakukan guru dan peneliti adalah, (1) gagasan dan keantusiasan dalam mengikuti proses pembelajaran, (2) kerja sama kelompok dalam membuat kerja sama kelompok dalam membuat rangkuman, dan (3) hasil rangkuman dengan memperhatikan kerapian tulisan, ejaan, tanda baca, dan 
Jurnal Darussalam; Jurnal Pendidikan, Komunikasi dan Pemikiran Hukum Islam Vol. IX, No 1: 32-49. September 2017. ISSN: 1978-4767 (Cetak), ISSN: 2549-4171 (Online)

kesempurnaan hasil rangkuman, mengenai tata bahasanya, model tulisanya, dan bobot serta kualitas rangkuman. Hasil pekerjaan dipresentasikan oleh perwakilan kelompok Pemberian nilai berkisar antara, sangat baik, baik, sedang, dan kurang.

\section{Kegiatan Penutup Pembelajaran}

Pada kegiatan ini dilakukan refleksi terhadap kegiatan pembelajaran yang telah berlangsung. Kegiatan refleksi dimanfaaatkan oleh guru dan siswa untuk menilai kemampuan siswa dan kelebihan atau kekurangan pada kegiatan pembelajaran yang telah berlangsung. Hasil kegiatan pembelajaran menyimak pada siklus I rata-rata kelas $75,125 \%$.Adapun hasil selengkapnya pada tabel berikut:

\section{Hasil Pembelajaran Menyimak Pada Siklus I}

\begin{tabular}{|c|c|c|c|c|c|c|c|c|}
\hline \multirow[b]{2}{*}{ No } & \multirow{2}{*}{$\begin{array}{l}\text { Nama Siswa } \\
\text { Dalam } \\
\text { kelompok }\end{array}$} & \multicolumn{4}{|c|}{ Skor Maksimal/Skor Pencapaian } & \multirow[b]{2}{*}{ Jumlah } & \multirow[b]{2}{*}{ Nilai } & \multirow[b]{2}{*}{ Persentase } \\
\hline & & Gagasan & $\begin{array}{l}\text { Kerja } \\
\text { sama }\end{array}$ & $\begin{array}{l}\text { Penggunaan } \\
\text { ejaan }\end{array}$ & Hasil & & & \\
\hline 1 & I & 4 & 4 & 3 & 3 & 14 & 3,50 & 87,50 \\
\hline 2 & II & 4 & 3 & 2 & 3 & 12 & 3,00 & 75,00 \\
\hline 3 & III & 3 & 3 & 3 & 2 & 12 & 3,00 & 75,00 \\
\hline 4 & IV & 3 & 3 & 3 & 2 & 11 & 2,75 & 68,75 \\
\hline \multicolumn{7}{|c|}{ Rata-rata } & 3,125 & 75,125 \\
\hline
\end{tabular}

Keterangan: 4 : baik, nilai 3:cukup, nilai 2: sedang, dan nilai 1 : kurang

Observasi dilakukan pada waktu tindakan pembelajaran berlangsung pada siklus I. kegiatan ini diarahkan pada hasil pengamatan yang ada dilapangan. Aktivitas pengamatan kegiatan pembelajaran pada siklus ini adalah (1) pembentukan kelompok, (2) mengatur tempat duduk siswa dan pengondisian kelas, (3) menentukan materi simakan, (4) menyimak materi yang di tayangkan guru, (5) berdiskusi untuk membuat rangkuman dari hasil simakan, (6) menyampaikan hasil rangkuman, (7) mengevaluasi teknik kerja kelompok yang telah dilaksanakan, dan (8) menyimpulkan hasil pelaksanaan teknik kerja kelompok.

Setelah pembelajaran siklus I selesai, guru (guru kulaburator) dan peneliti bertemu untuk merefleksi (mengkaji ulang) hasil dari proses pembelajaran menyimak dengan teknik kerja kelompok pada siswa kelas VIII SMP Darussalam Blokagung Tegalsari Banyuwangi siklus I. Hasil tindakan berupa proses dan produk. Dari hasil refleksi yang dilaksanakan secara kolaborasi dengan guru 
kelas VIII dapat dikemukakan bahwa hasil tindakan yang berupa proses pada tiap tahap tindakan sudah dilaksaanakan dengan baik, tetapi masih diperlukan penyesuaian dan perbaikan demi perbaikan proses kegiatan belajar mengajar. Dari hasil yang ditemukan ternyata kerjasama dalam kelompok belum berjalan dengan baik sesuai yang diharapkan pada kegiatan ini. Oleh karena itu, kegiatan diskusi pelaksanaanya perlu diperbaiki dan dikondisikan sesuai dengan porsinya agar siswa lebih aktif mengemukakan pendapat.

Berdasarkan hasil refleksi seluruh tindakan pada siklus I ternyata masih ditemukan beberapa hal yang perlu mendapat perhatian dan perbaikan karena nilai rata-rata kelas masih75,125\%. Karena hasil siklus I belum maksimal maka dirancang untuk mengadakan kegiatan sikluss II.

\section{Hasil Tindakan Siklus II}

Sebelum pelaksanaan siklus II guru dan peneliti menyusun perencanaan. Perencanaan ini dilakukan pada hari kamis tanggal 8 Mei 2014 di ruang guru SMP Plus Darussalam Blokagung Desa Karangdoro Kecamatan Tegalsari Kabupaten Banyuwangi. Akhir diskusi diperoleh kesepakatan bahwa pelaksanaan tindakan siklus II akan dilaksanakan pada hari senin tanggal 12 Mei 2014 dilaksanakan selama 2 jam pelajaran ( 2 x 40 menit) pukul $12.40 \mathrm{Wib}$ s/d pukul 13.20 Wib. Pelaksanaan tindakan siklus II dilakukan melalui beberapa kegiatan.

\section{Kegiatan Pendahuluan Pembelajaran}

Kegiatan pendahuluan pembelajaran berupa apersepsi tentang pelaksanaan pada siklus I. Kegiatan pendahuluan pembelajaran berupa ucapan salam, penyampaian tujuan pembelajaran yang akan disampaikan, pengarahan yang berupa penjelasan mengenai pelaksanaan pembelajaran dan memotivasi siswa agar lebih giat dalam mengikuti setiap pelaksanaan pembelajaran. Kegiatan pendahuluan pembelajaran dilaksanakan selam 20 menit. Penggunaan waktu tersebut telah sesuai alokasi waktu yang tersedia. Hal ini dilakukan dengan tujuan untuk memberikan situasi dan kondisi pembelajaran yang lebih hidup dan menyenangkan sehingga pembelajaran dapat berjalan dengan baik. 


\section{Kegiatan Inti Pembelajaran}

Setelah pengaturan tempat duduk dan tiap anggota kelompok sudah menempati tempatnya masing-masing maka akan dimulai kegiatan pembelajaran. Guru mempersiapkan materi simakan dan tiap siswa menyimak yang ditayangkan dengan media Audio Visual kemudian berdiskusi dan membuat rangkuman tentang materi yang disimak. Selanjutnya guru mengambil mengambil dan membagikan silang kepada tiap kelompok yang berbeda untuk mempresentasikan hasil rangkuman tiap kelompok. Guru memberikan evaluasi dari tiap-tiap kelompok. Penilaian yang dilakukan adalah: (1) cara penyampaian dari wakil tiaptiap kelompok, (2) keantusiasan dalam penyampaian, (3) ide bertanya dari masing- masing tiap kelompok, dan (4) tanggapan dari wakil masing-masing kelompok, selain hasil presentasi dari tiap-tiap kelompok penilaian yang dilakukan oleh guru adalah hasil rangkuman, mengenai tata bahasanya, model tulisan, dan bobot serta kualitas rangkuman. Guru memberikan penilaian dengan jeli. Pemberian nilai nilai berkisar antara sangat baik, baik, sedang, dan kurang.

\begin{tabular}{|l|l|l|l|l|l|}
\hline \multirow{2}{*}{ NO } & \multicolumn{5}{|c|}{ NAMA KELOMPOK } \\
\cline { 2 - 6 } & I & II & III & IV & V \\
\hline 1 & $\begin{array}{l}\text { Anggun } \\
\text { Pertiwi }\end{array}$ & $\begin{array}{l}\text { Iqlima Nur } \\
\text { Faizah }\end{array}$ & $\begin{array}{l}\text { Mufarikatuz } \\
\text { Zuhdataini }\end{array}$ & $\begin{array}{l}\text { Nurul } \\
\text { Fitriyani }\end{array}$ & $\begin{array}{l}\text { Veni Nurita } \\
\text { Sari }\end{array}$ \\
\hline 2 & $\begin{array}{l}\text { Aulia } \\
\text { nikmatul } \\
\text { maula }\end{array}$ & $\begin{array}{l}\text { Jihan Nafiatul } \\
\text { Amalia }\end{array}$ & $\begin{array}{l}\text { Nadia Fitriatus } \\
\text { Sholihah }\end{array}$ & $\begin{array}{l}\text { Rona } \\
\text { Rizqotul } \\
\text { Izzah }\end{array}$ & $\begin{array}{l}\text { Vina Nailil } \\
\text { Faza }\end{array}$ \\
\hline 3 & Dewi lyien ien & $\begin{array}{l}\text { Lu'luil } \\
\text { Maknun }\end{array}$ & $\begin{array}{l}\text { Nadia Ilma } \\
\text { Rohestina }\end{array}$ & $\begin{array}{l}\text { Shanggita } \\
\text { Dewi }\end{array}$ & $\begin{array}{l}\text { Vina } \\
\text { rohmatul } \\
\text { Fitriah }\end{array}$ \\
\hline 4 & $\begin{array}{l}\text { Diana Novita } \\
\text { Sari }\end{array}$ & Lutfi Rahayu & $\begin{array}{l}\text { Nadiatus } \\
\text { Sholehah }\end{array}$ & $\begin{array}{l}\text { Siti } \\
\text { Alfarida }\end{array}$ & $\begin{array}{l}\text { Zuhroina } \\
\text { Nur Fuadah }\end{array}$ \\
\hline 5 & $\begin{array}{l}\text { Elia Hani } \\
\text { Safitri }\end{array}$ & $\begin{array}{l}\text { Miftahul } \\
\text { hidayah }\end{array}$ & $\begin{array}{l}\text { Nafisatul } \\
\text { Imamah }\end{array}$ & $\begin{array}{l}\text { siti } \\
\text { Hafdlotul } \\
\text { Fitriah }\end{array}$ & $\begin{array}{l}\text { Mecca } \\
\text { nurrofi P }\end{array}$ \\
\hline 6 & $\begin{array}{l}\text { Evi Nur } \\
\text { Azizah }\end{array}$ & $\begin{array}{l}\text { Miranda } \\
\text { Wardaniyah }\end{array}$ & $\begin{array}{l}\text { Nurma Indana } \\
\text { Zulfa }\end{array}$ & $\begin{array}{l}\text { Uwaisa } \\
\text { Qornia }\end{array}$ & $\begin{array}{l}\text { Nur Ruyadh } \\
\text { Fitri }\end{array}$ \\
\hline
\end{tabular}

\section{Kegiatan Penutup Pembelajaran}

Pada kegiatan ini dilakukan refleksi terhadap kegiatan pembelajaran yang telah berlangsung. Kegiatan refleksi dimanfaaatkan oleh guru daan siswa untuk menilai kemampuan siswa dan kelebihan atau kekurangan pada kegiatan 
pembelajaran yang telah berlangsung. Kelebihan yang dimiliki adalah keantusiasan dan keseriusan serta kerja sama siswa dalam mengikuti semua langkah-langkah pembelajaran. Kelebihan dapat dijadikan modal untuk keberhasilan siklus II ini dan kelemahanya sudah dapat diminimalisir.. Hasil kegiatan pembelajaran menyimak pada siklus II rata-rata 87,50 \%. Adapun hasil selengkapnya pada taabel berikut:

\begin{tabular}{|c|c|c|c|c|c|c|c|c|}
\hline \multirow[b]{2}{*}{ No } & \multirow{2}{*}{$\begin{array}{l}\text { Nama Siswa } \\
\text { Dalam } \\
\text { Kelompok }\end{array}$} & \multicolumn{4}{|c|}{ Skor Maksimal/Skor Minimal } & \multirow[b]{2}{*}{ Jumlah } & \multirow[b]{2}{*}{ Nilai } & \multirow{2}{*}{$\begin{array}{l}\text { Persen } \\
\text { ta } \\
\text { se }\end{array}$} \\
\hline & & $\begin{array}{l}\text { Gagasa } \\
\mathrm{n}\end{array}$ & $\begin{array}{l}\text { Kerja } \\
\text { Sama }\end{array}$ & $\begin{array}{l}\text { Penggunaan } \\
\text { Ejaan }\end{array}$ & Hasil & & & \\
\hline 1 & I & 4 & 4 & 4 & 3 & 15 & 3,75 & 93,75 \\
\hline 2 & II & 4 & 4 & 3 & 3 & 14 & 3,50 & 87,50 \\
\hline 3 & III & 4 & 4 & 3 & 3 & 14 & 3,50 & 87,50 \\
\hline 4 & IV & 3 & 4 & 3 & 3 & 13 & 3,25 & 81,25 \\
\hline \multicolumn{7}{|c|}{ Rata-rata } & 3,50 & 87,50 \\
\hline
\end{tabular}

Table Hasil Pembelajaran Menyimak Pada Siklus II

Keterangan: 4 : baik, nilai 3:cukup, nilai 2: sedang, dan nilai 1 : kurang

Observasi dilakukan pada waktu tindakan pembelajaran berlangsung pada siklus II. kegiatan ini diarahkan pada pengamatan yang ada dilapangan. Aktivitas pengamatan kegiatan pembelajaran pada siklus ini meliputi kegiatan guru dan siswa yaitu (1), pembagian kelompok, (2) pengaturan tempat duduk sesuai dengan kelompok masing-masing, (3) menentukan wacana yang akan disampaikan, (4) mendengarkan dan menyimak materi pembelajaran, (5) berdiskusi membuat rangkuman, (6) mengumpulkan hasil simakan, (7) membagi hasil simakan secara silang, dan (8) menunjuk dari perwakilan keolmpok maju kedepan membacakan hasil simakan kelompok lain.

Refleksi dilaksanakan setelah selesai pelaksanaan tindakan pembelajaran siklus II. Kegiatan ini dilakukan secara kolaboratif bersama guru kelas VIII. Selain itu kegiatan ini juga dilakukan dengan memperhatikan respon yang disampaikan siswa saat wawancara diakhir tindakan siklus II. Refleksi diarahkan pada (1) Kegiatan pendahuluan pembelajaran. Pada pelaksanaan kegiatan pendahuluan pembelajaran siklus II, sudah dapat diatasi dengan yang lebih tegas dan juga bisa mengefektifkan kerja sama masing-masing kelompok. Sehingga siswa dalam mengikuti kegiatan pembelajaran dapat bekerjasama secara efektif. (2) Kegiatan inti pembelajaran. Refleksi pada kegiatan ini dilakukan terhadap 
hasil tindakan berupa proses dan produk. Dan hasil refleksi yang dilaksanakan secara kolaboratif dengan guru kelas VIII dapat dikemukakan bahwa hasil tindakan yang berupa proses pada tiap tahap tindakan sudah dilakukan dengan baik. Pada beberapa proses kegiatan yang telah dilakukan siswa mulai dari memilih anggota kelompok, mengatur tempat duduk, penempatan anggota kelompok sesuai dengan kelompok, menyimak maateri pembelajaran, membuat rangkuman dan membacakan hasil simakan berupa rangkuman. Dari hasil temuan ternyata kerja sama dalam kelompok sudah dapat berjalan dengan baik sesuai yang diharapkan pada kegiataan ini.

Dalam membacakaan hasil simakan berupa hasil rangkuman, guru memberi contoh cara membaca yang baik. Anak yang menjadi wakil dari kelompoknya membacakan hasil karya dari kelompok lain dapat menjalankan tugas dengan baik, membaca tidak terlalu tergesa-gesa, dengan suara lantang, tegas dan penuh dengan semangat. Alokasi waktu sudah diperhatikan dengan baik, sehingga meteri bisa selesai dan tidak mengganggu proses belajar mengajar berikutnya.(3) kegiatan Penutup Pembelajaran. Berdasarkan hasil refleksi seluruh tindakan pada siklus II dapat disimpulkan bahwa penerapan teknik kerja kelompok, telah dapat memperbaiki dalam pembelajaran menyimak di kelas VIII SMP Plus Darussalam Blokagung Banyuwangi. Hal ini dilihat dari hasil pengamatan awal nilai rata-rata kelas adalah $71,6 \%$, dan pada siklus I rata-rata kelas $75,125 \%$ sedangkan nilai rata-rata kelas pada siklus II yaitu $87,50 \%$. Karena hasil siklus II sudah baik maka tidak diperlukan lagi tindakan siklus berikutnya.

\section{F. Pembahasan}

\section{Relevansi antara Temuan Penelitian dengan Kurikulum}

Dalam Undahg-Undäng Sistem Pendidikan Nasional No. 20 tahun 2003 pasal 35 ayat 1 bahwa: "Stañdar nasional terdiri atas isi, proses, kompetensi lulusan, tenaga kependidikan, sarana dan prasarana, pengelolaan, pembiayaan, dan penilaian pendidikan yang harus ditingkatkan secara berencana dan berkala" Berdasarkan kurikulum KTSP tersebut pembelajaran mendengarkan/menyimak untuk kelas VIII SMP Plus Darussalam Blokagung Banyuwangi, maka standar kompetensi yang digunakan adalah 9. Memahami isi berita radio/televisi yang disampaikan dengan menggunakan media audio visual. Sedangkan kompetensi 
Jurnal Darussalam; Jurnal Pendidikan, Komunikasi dan Pemikiran Hukum Islam Vol. IX, No 1: 32-49. September 2017. ISSN: 1978-4767 (Cetak), ISSN: 2549-4171 (Online)

dasar mata pelajaran bahasa Indonesia untuk kemampuan mendengarkan dan menyimak siswa sekolah menengah pertama kelas VIII semester II adalah 9.1 Menemukan pokok-pokok berita (apa, siapa, mengapa, di mana, kapan, dan bagaimana) yang didengar atau ditonton melalui radio/televisi dan 9.2 Mengemukakan kembali berita yang didengar/ditonton melalui radio/ televisi yang disampaikan dengan menggunakan media audio visual. Berdasarkan kompetensi dasar tersebut hasil belajar yang tercantum dalam deskripsi kurikulum adalah menyimak berita. Kompetensi dasar adalah pengetahuan, keterampilàn, dan sikap yang minimal yang harus dikuasai peserta didik untuk menunjukkan bahwa siswa telah menguasai standar kompetensi yang ditetapkan (Majid, 2008: 43).

Pada siklus I tahapan langkah pembelajarannyan adalah menentukan anggota kelompok tapi dalam menentukan anggota kelompok masing-masing berdasarkan teman yang disenangi saja. Pada siklus I dalam memilih anggota kelompok sudah teratur, sudah dilaksanäkan secara adil berdasarkan pemerataan kepandaian siswa dan guru tinggal mengarahkannya. Pada saat rnenyimak siswa masih banyak yang tidak dapat menyimpan/mengingat kalimat/kalimat yang disampaikan guru secara Iisan, siswa sebagian bingung mau berbuat apa, namun pada siklus II siswa telah dapat mengatasi kesulitan yang dihadapinya. Berdasarkan uraian tersebut menunjukkan bahwa dalam penelitian yang telah dilaksanakan sudah menunjukkan kesesuaian antara kompetensi dasar yang diinginkan dengan pelaksanaan pembelajaran.

\section{Relevansi antara Temuan Penelitian dengan Tujuan Umum Pembelajaran}

Untuk mencapai tujuan pembelajaran menyimak dengan menggunakan media Audio Visual dalam penelitian ini berpedoman pada indikator yang telah dicantumkan pada kurikulum. Rumusan indikator yang ada pada kurikulum adalah mengutarakan kembali materi simakan dan menyampaikan kembali isi materi yang telah di rangkum. Hasil siklus I siswa masih banyak mengalami kendala terutama dalam hal menyimpulkan hasil simakan, karena tiap-tiap kelompok masih belum konsentrasi dalam menerima informasi dari guru sehingga masih banyak kesalahan dalam menyimpulkan hasil simakan, baik kelengkapan infonnasi maupun ejaan yang digunakan dan siklus II hasil yang dicapai sudah 
Jurnal Darussalam; Jurnal Pendidikan, Komunikasi dan Pemikiran Hukum Islam Vol. IX, No 1: 32-49. September 2017. ISSN: 1978-4767 (Cetak), ISSN: 2549-4171 (Online)

baik dan kesalahan sudah dapat diminimalisir sehingga dapat dikatakan bahwa pembelajaran menyimak berhasil.

\section{Relevansi antara Temuan Penelitian dengan Guru}

Hasil penelitian yang ditunjukkan pada bab IV siswa mengutarakan kembali isi berita tayangan yang didengar. Keberhasilan yang telah dicapai bukan dari siswa sendiri namun peran guru juga sangat mempengaruhi keberhasilan pembelajaran tersebut. Minat, bakat, kemampuan, dan potensi-potensi yang dimiliki oleh peserta didik, tidak akan berkembang secara optimal tanpa bantuan guru. (Mulyasa, 2005: 35). Untuk kelancaran dalam pelaksanaan pembelajaran yang perlu diperhatikan dan dipersiapkan guru adalah membantu pertumbuhan dan perkembangan para peserta didik secara individu, karena antara satu peserta didik dengan peserta didik yang lain memiliki perbedaan yang sangat mendasar, dan memberikan kernudahan belajar bagi para siswa agar dapat mengembangkan potensi yang dimiliki dengan benar. Pada semua kegiatan, guru bersama siswa mengadakan refleksi pembelajaran yang telah berlangsung.

\section{Relevansi antara Temuan Penelitian dengan Siswa Pembelajar}

Penekanan pembelajaran yang diharapkan pada saat ini adalah pembelajaran yang aktif, inovatif, komunikatif, efektif, dan menyenangkan. Pembelajaran aktif yang diharapkan adalah siswa lebih aktif mengikuti proses pembelajaran pada setiap kegiatan pelaksanaan pembelajaran. Pada penelitian ini menunjukkan bahwa keaktifan, keantusiasan, dan kedisiplinan siswa dalam mengikuti semua langkah pembelajaran yang berlangsung sudah baik. Semua siswa setelah pelaksanaan pembelajaran merasa senang karena telah berhasil sesuai dengan yang diharapkan.

\section{Relevansi antara Temuan Penelitian dengan Kegiatan Pembelajaran}

Hakikat belajar bahasa adalah belajar komunikasi, oleh karena itu pembelajaran bahasa Indonesia adalah untuk meningkatkan kemampuan siswa dalam berkomunikasi dengan bahasa Indonesia secara lisan maupun tulis. Aktivitas belajar mengajar yang dilaksanakan pada pembelajaran menyimak dengan menggunakan teknik kerja kelompok, dimulai dari perencanaan tindakan, pelaksanaan tindakan, dan refleksi. Rencana pelaksanaan pembelajaran disusun 
bertujuan agar dalam proses belajar mengajar nanti tujuan yang diinginkan dapat tercapai secara maksimal. Pelaksanaan tindakan kegiatan proses pembelajaran menyimak dengan menggunakan teknik kerja kelompok dilaksanakan dengan dua siklus, tiap siklus terdiri dan tiga kegiatan. Kegiatan pembelajaran itu adalah kegiatan awal, kegiatan inti dan kegiatan akhir. Setelah selesai mengevaluasi kegiatan siswa dan telah menerima masukan dan siswa dan guru, maka dalam pelaksanaan pembelajaran menyimak berita dapat dikatakan sudah baik.

\section{Relevansi antara Temuan Penelitian dengan Metode Pembelajaran}

Metode yang digunakan bertujuan untuk mencapai tujuan yang diinginkan dalam meningkatkan kemampuan menyimak berita dengan menggunakan media audio visual. Penggunaan metode yang bervariasi akan sangat membantu peserta didik dalam mencapai tujuan pembelajaran. Media yang digunakan dãlam pembelajaran menyimak berita adalah Audio Visual . Penggunaan media tersebut dilakukan pada proses belajar mengajar yang berlangsung dengan kegiatan pembelajaran menyimak berita.

\section{Relevansi antara Temnan Fenelitian dengan Sarana Prasarana}

Sarana prasarana dapat digunakan untuk menunjang keberhasilan proses pembelajaran, apabila sarana prasarana tersebut penggunaannya digunakan secara tepat. kegiatan pembelajaran yang dilaksanakan memerlukan sarana dan prasarana untuk menunjang keberhusilan pembelajaran yang dilaksanakan tersebut. Pada penelitian ini sarana yang digunakan dalam proses belajar mengajarnya adalah ruang kelas, meja dan kursi, halaman sekolah dan Ruang kelas. Meja kursi digunakan siswa untuk kegiatan tulis-menulis. Pelaksanaan pembelajaran dilaksanakan di dalam ruang kelas dengan tujuan agar tidak mengganggu kelas yang lain, yang juga sama-sama melaksanakan pembelajaran.

\section{G. Simpulan}

Simpulan dari penggunakan media Audio Visual pada pembelajaran menyimak berita siswa kelasVIII SMP Plus Darussalam Blokagung Banyuwangi dapat diuraikan sebagai berikut. Setelah pengamatan awal selesai, guru (guru kulaburator) dan peneliti bertemu untuk (mengkaji ulang) hasil dari proses pembelajaran menyimak siswa kelas VIII SMP PlusDarussalam Blokagung 
Tegalsari Banyuwangi. Berdasarkan hasil pengamatan awal dapat direfleksikan sebagi berikut:

1. Kemampuan menyimak siswa dengan lisan masih sangat minim sehingga perlu adanya sebuah metode yang dapat meningkatkan kemampuan keterampilan menyimak.

2. Siswa belum terampil dalam menyimak dan membuat rangkuman hasil simakan dengan media lisan

3. Siswa dalam menyampaikan hasil simakan alurnya masih kurang runtut dan jelas.

Perbaikan pada siklus I adalah pelaksanaan pembelajaran menyimak melalui metode media audio visual teknik kerja kelompok harus ditekankan kepada siswa untuk lebih terampil menyimak.

\section{a. Siklus I}

Tindakan siklus I yang dilaksanakan selama 80 menit menunjukkan hasil yang baik, yaitu nilai rata-rata kelas sudah mencapai standar nilai yaitu 75, \%,karena siswa telah mampu menguasai ketentuan standar kurikulum pendidikan mata pelajaran Bahasa Indonesia aspek menyimak dengan metode media audio visual teknik kerja kelompok dan mampu menemukan ide-ide pokok, berdiskusi dengan baik, merangkum hasil simakan, dan menyampaikan kembali hasil rangkuman. Namun pembelajarn menyimak melalui metode media audio visual teknik kerja kelompok belum maksimal.

Berdasarkan pengamatan dan analisa hasil kemampuan menyimak, maka guru dan peneliti sepakat untuk menambah siklus untuk lebih meningkatkan lagi kualitas dalam keterampilan meyimak melalui metode media audio visual teknik kerja kelompok.

\section{b. Siklus II}

Tindakan siklusII yang dilaksanakan selama 80 menit menunjukan hasil yang lebih baik, yaitu nilai rata-rata kelas mencapai 87,50\% dan siswa telah mampu berdiskusi dengan baik, merangkum hasil simakan dengan benar dan menyampaikan kembali isi rangkuman tersebut dengan runtut dan jelas.

Berdasarkan pengamatan dan analisa hasil pembelajaran maka guru dan peneliti sepakat untuk mengakhiri siklus tindakan dalam penelitian 
menyimak.Melihat perubahan dalam keterampilan menyimak melalui metode media audio visual teknik kerja kelompok dalam setiap siklusnya, dapat diambil kesimpulan bahwa:

1) Terdapat kemampuan keterampilan menyimak siswa kelas VIII SMP Plus darussalam melalui metode media audio visual teknik kerja kelompok.

2) Terjadi peningkatan proses dalam setiap kegiatan penelitian. Karena ada peningkatan keterampilan menyimak pada tahap pertama, yaitu: (1) kesenangan dan kegairahan belajar dalam mengikuti proses pembelajaran sudah kelihatan, (2) antusias dan kerjasama dalam mengikuti diskusi dan pembentukan kelompok sudah baik, (3) ketekunan, kerjasma, dan kreativitas siswa dalam mengikuti proses pembelajaran sudah dilakukan dengan baik dan penuh kedisiplinan. Dan peningkatan keterampilan menyimak pada tahap kedua yaitu: (1) keaktifan dan kreativitas siswa dalam menata anggota kelompok, (2) antusias dan kerjasama dalam menerima materi simakan yang disampaikan oleh guru, (3) semangat dan kerjasam siswa dalam membuat rangkuman hasil simakan, dan (4) keberanian siswa dalam menyampaikan pendapat. Sedangkan peningkatan keterampilan menyimak pada tahap akhir adalah (1) kedisiplinan dalam mengikuti proses pembelajaran, (2) keberanian dalam mempresentasikan hasil kerja kelompok, dan (3) keberanian dalam memberikan tanggapan terhadap pelaksanaan kegiatan pembelajaran. Selain itu adapula peningkatan keterampilan dalam aktivitas mengoreksi pekerjaan yang telah dilakukan dan cara memberi tanggapan terhadap kegiatan pembelajaran yang telah dilakukan.

3) Terdapat peningkatan hasil dalam keterampilan menyimak di setiap kegiatan penelitian. Hal ini berdasarkan hasil penelitian awal yaitu nilai rata-rata kelas mencapai 71,6\% sedangkan siklus I yaitu: 75,125\% dan nilai rata-rata kelas pada siklus II adalah $87,50 \%$. 


\section{H. Saran}

Dalam penelitian tindakan kelas ini saran ditujukan pada

1. SMP Plus Darussalam blokagungTegalsari Banyuwangi Melihat kegunaan metode media audio visual teknik kerja kelompok dalam peningkatan keterampilan menyimak sudah sepatutnya pihak sekolah untuk memfasilitasi beberapa instrument yang menunjang keberhasilan dalam proses pembelajaran. Hal itu sangat banyak sekali manfaatnya sehingga memudahkan guru menerapkan metode ini hasilnya pun kembali kepihak lembaga, Manakala lembaga itu melengkapi beberapa alat pembantu guna menunjang keberhasilan pembelajaran yang akan menarik siswa agar lebih giat belajar. Selanjutnya agar penggunaan metode media audio visual teknik kerja kelompok untuk peningkatan keterampilan menyimak, pihak sekolah harus selalu mengingatkan kepada guru bahasa harus lebih kreatif dan inovatif dalam penerapan metode ini sehingga tidak membuat jenuh para peserta didik / siswa. Bagi Guru Penggunaan metode media audio visual teknik kerja kelompok untuk meningkatkan keterampilan menyimak sangatlah potensial. Hal ini karena guru sebagai aktor pendidikan. Meskipun guru disini hanya sebagai fasilitator akan tetapi arahan dan sentuhan langsung dengan murid akan lebih mengena terhadap keberhasilan metode ini. Jadi, keterampilan guru dalam mengolah metode ini sangatlah menunjang sekali dalam proses belajar mengajar menyimak.

2. Bagi PenelitiL anjut Penelitian penggunaan metode media audio visual teknik kerja kelompok dalam meningkatkan ketermpilan menyimak layak untuk terus diteliti. Karena proses belajar mengajar terus berkembang seiring perkembangan dunia pendidikan. Hal ini berdasarkan metode- metode yang terus berkembang di dalam dunia pendidikan sehingga persaingan antar metode pembelajaran sangatlah tidak mustahil. Jadi penggunaan metode ini harus selalu diteliti dan telaah kembali apakah masih relevan atau tidak penggunaan metode media audio visual dengan teknik kerja kelompok ini.

\section{Daftar Pustaka}

Arsyad, Dr. Azhar. 2011. Media Pembelajaran. Jakarta: Rajawali Pers. Dewik.dkk. 2013. Terampil Berbahasa Indonesia Yogyakarta. Andi Offset. 
Jurnal Darussalam; Jurnal Pendidikan, Komunikasi dan Pemikiran Hukum Islam

Vol. IX, No 1: 32-49. September 2017. ISSN: 1978-4767 (Cetak), ISSN: 2549-4171 (Online)

Djiwandono,M. Soenardi. 2011. Tes Bahasa Pegangan Bagi Pengajar Bahasa. Malang: Universits Negri Malang.

Haryadi dan Zamzani. 1999/2000. Peningkatan Keterampilan Berbahasa Indonesia. Departemen Pendidikan dan Kebudayaan Direktorat Jenderal Pendidikan Tinggi.

Iskandar. 2012. Penelitian Tindakan Kelas. Jakarta Utara. Referensi. GP Press Grup.

Iskandarwassid dan Dadang. 2011. Strategi Pembelajaran Bahasa. Bandung: PT Remaja Rosdakari.

Majid. Abdul. 2006. PerencanaanPembelajaran. Bandung: Remaja Rosdakarya

Mulyasa. E. 2005. Menjadi Guru Profesional. Bandung: RemajaRosdakarya.

St. Y. Slamet dan Amir. 1996. Peningkatan Keterampilan Berbahasa Indonesia (Bahasa Lisan dan Bahasa Tertulis). Surakarta: Universitas Sebelas Maret.

Tarigan, Henry Guntur. 2008. Menyimak: Sebagai Suatu Keterampilan Berbahasa. Bandung: Angkasa. 